\title{
Inside Washington
}

\section{Sara Case \\ Associate Director \\ ALA Washington Office}

\section{Library of Congress \\ Thomas JefFerson BuIlding}

By early February 1976, the Library of Congress James Madison Memorial Library Building seemed to be once again on the track to completion as originally planned (for the library, not for House office space). Focus then shifted abruptly to the Library of Congress Thomas Jefferson Building.

This time, the eyes of congressional leaders were not gleaming with fine new office space as they looked at LC. They were proposing instead to give a fine new name to the library's annex building.

Sen. Howard Cannon (D-Nev.) and Rep. Lucien Nedzi (D-Mich.) are joint sponsors of legislation to rename the annex building (just across Second Street from the main library building), and their proposal, fitting in this Bicentennial year, is to call it the Library of Congress Thomas Jefferson Building.

The Cannon bill (S 2920) was introduced February 3 and referred to the Senate Committee on Rules and Administration, which he chairs, while the Nedzi bill (HR 11712) came a day later and was referred to the House

\section{Recent ACRL Publications}

Available from ACRL Office, 50 E. Huron St., Chicago, IL 60611-Networks and the University Library, 2d printing, $\$ 3.00$ prepaid, $\$ 5.00$ if billing is required: proceedings of an institute presented by the University Libraries Section, 1973.

Available from ALA Order Dept., 50 E. Huron St., Chicago, IL 60611-Faculty Status for Academic Librarians, $\$ 3.50$ : a history and policy statements; Books for College Libraries, $2 \mathrm{~d}$ ed., $\$ 65.00$ for 6-vol. set, separate volumes $\$ 12.50$ each: 40,000 titles selected for the four-year undergraduate library; The Role of the Beginning Librarian in University Libraries, by Ralph M. Edwards (ACRL Publications in Librarianship, no.37), $\$ 6.50$.
Administration Committee's Subcommittee on Library and Memorials, chaired by Lucien Nedzi.

The bill is expected to pass, the annex thus renamed, and the idea is reasonably attributable to Daniel J. Boorstin, the new Librarian.

\section{Japanese Library Collections}

A Japanese-American cultural exchange program was established last fall by enactment of the Japan-United States Friendship Act (Public Law 94-118). The new law authorizes, among other things, support for major Japanese library collections at American colleges and universities, as well as assistance for scholarly research and Japanese language studies.

The Friendship Act creates a trust fund in the U.S. Treasury with proceeds from the 1971 Okinawa Reversion Agreement and other funds available in U.S. accounts in Japan, to be used to promote scholarly and cultural activities between the two countries.

The program is to be administered by a commission, headed by Dr. John W. Hall, professor of history, Yale University. At this writing a decision is still to be made on the location of the commission office.

Libraries interested in learning more might write to Professor Hall ( 237 Hall of Graduate Studies, Yale University, New Haven, CT 06520) and ask to be put on a mailing list to receive information about the program when it is available.

To receive a copy of the public law (PL 94-118) authorizing the new exchange program, write the Senate Document Room, U.S. Capitol, Washington, DC 20510, or better still, write your senator and ask him to send you one.

\section{CENSUS BUREAU SEEKS COMMENTS}

The U.S. Bureau of the Census reports that the basic design of the questionnaire to be used in the 1980 census will be completed by spring 1977. The bureau now is seeking recommendations from as wide a range of users and potential users of decennial census data as possible. Members of ACRL who wish to comment upon the amount and kind of information to be collected and how that information might be tabulated are invited to send suggestions or comments to the Director, U.S. Bureau of the Census, Washington, DC 20233. 